\section{Growth surveillance in the context of the Primary Public Healthcare Service Network in Brazil: literature review}

\section{Vigilância do crescimento no contexto da Rede Básica de Saúde do SUS no Brasil: revisão da literatura}

Dixis Figueroa Pedraza1

1Programa de Pós-graduação em Saúde Pública. Departamento de Enfermagem. Universidade Estadual da Paraíba.Av. das Baraúnas, 351. Campus Universitário. Bairro Bodocongó. Campina Grande, PB, Brasil. CEP: 58.109-753. E-mail: dixisfigueroa@gmail.com

\begin{abstract}
Objectives: to identify and analyze the scientific literature on child growth monitoring in the context of the primary public healthcare service network in Brazil, focusing on the main problems detected in studies.

Methods: the review was based on searches ofSciELO, Lilacs and PubMed databases to identify articles published between 2006 and 2014. The articles were categorized according to the analytical categories of structure (items needed to carry out primary activities) or work processes (set of activities and procedures used in the management of resources).

Results: of the 16 articles included in this review, only six dealt with structure and, in these, thetraining of professionals and availability of protocols were the most frequently identified problems. Processes, addressed in 15 articles, highlighted the underutilization of Child Health Handbook to record growth measurements and the adoption of guidelines on the basis of notes taken.

Conclusions: the difficulties found demonstrate the everyday circumstances of the public health service which have a detrimental effect on growth surveillance.
\end{abstract}

Key words Primary health care, Health services evaluation, Nursing care, Community medicine, Nutritional surveillance

\section{Resumo}

Objetivos: identificar e analisar o perfil da produção cientifica sobre a vigilância do crescimento infantil no contexto da rede básica de saúde do SUS no Brasil, focando nos principais problemas detectados nas pesquisas.

Métodos: o estudo foi desenvolvido com base na consulta nas bases bibliográficas SciELO, Lilacs e PubMed para identificar artigos publicados entre 2006 e 2014. Os artigos foram categorizados segundo as categorias analiticas de estrutura (itens necessários à realização das ações de atenção primária) ou processo de trabalho (conjunto de atividades e procedimentos empregados no manejo dos recursos).

Resultados: dos 16 artigos incluídos na revisão, apenas seis trataram sobre a estrutura, sendo o treinamento dos profissionais e a disponibilidade de protocolos os problemas identificados como mais recorrentes. O processo, abordado em 15 artigos, destaca a subutilização da Caderneta de Saúde da Criança em relação ao registro das medidas de crescimento e à adoção de orientações sob a base das anotações realizadas.

Conclusões: as dificuldades encontradas manifestam circunstâncias do cotidiano dos serviços públicos de saúde com prejuízos à vigilância do crescimento.

Palavras-chave Atenção primária à saúde, Avaliação de serviços de saúde, Cuidados de enfermagem, Medicina comunitária, Vigilância nutricional 


\section{Introduction}

Child growth monitoring is one of the guiding principles of basic health measurement and its main purpose is to assess the adequacy of growth and to identify deficiency at an early stage, before the child reaches the status of undernutrition.1,2 The main benefits of growth monitoring are reductions in undernutrition, morbidity and mortality among young children. ${ }^{3}$ This action provides a necessary basis for the evaluation of health conditions, as well as a reduction in child morbidity and mortality. ${ }^{1}$

In Brazil, in the context of Primary Health Care, child growth monitoring and development occurs through childcare consultation. This consultation becomes effective when routines are established and assistance is offered on a regular, systematic, comprehensive and individualized basis. This surveillance during routine visits not only provides access to services, but also consolidates ties, promotes acceptance and contributes to comprehensive care. It also enables the identification of major health problems, as well as the provision and evaluation of health care services. 4,5

In childcare consultation, effective monitoring requires a good level of record-keeping in terms of monitoring tools, high coverage rates, regular attendance and accurate measurements. The training of professionals and maternal education in health care are basic conditions for the good performance of health actions. ${ }^{6}$ However, the reality diverges from the recommendations of the Ministry of Health, with deficiencies in terms of both the involvement of professionals and growth surveillance. 7,8

Recently published review articles have enhanced the scientific literature on topics related to food and nutrition actions in the Primary Health Care System. These studies focus mainly on the profile of research groups and actions related to food and nutrition within the Family Health Strategy, ${ }^{9}$ scientific nutrition production in the Primary Health Care System, ${ }^{10}$ scientific knowledge produced by the Child Health Record as a child health surveillance instrument, 11 the factors that hinder the proper use of the Child Health Record by health professionals 12 and the use of the Child Health Record with an emphasis on growth and development. 13 Given the absence of reviews with a specific focus on failures and difficulties regarding growth monitoring, this aim of the present study was to reveal shortcomings in the development of this action as a way of promoting changes in its operation.

The present study thus aimed to identify and analyze the scientific literature on child growth monitoring in the context of the primary public healthcare service network in Brazil, focusing on the main problems detected in the studies.

\section{Methods}

A literature review was carried out with the following question in mind: what scientific production was there on child growth monitoring within the (Unified Health System) SUS health network in Brazil from 2006 to 2014 ? The study was based on searches ofthe Scientific Electronic Library Online (SciELO), the Latin American and Caribbean Health Sciences (Lilacs) and the National Library of Medicine, United States (PubMed) databases. The search considered articles published between 2006 and the search date (5/24/2015) in English, Portuguese and Spanish. The period beginning in 2006 was chosen because 2005 was the year the Child Health Handbook was created 14 and 2006 the year of publication of the new growth curves of the World Health Organization, 15 an important milestones in health surveillance actions.

Two sets of intersecting bibliographic search terms relating to "PRIMARY HEALTH CARE" or "NURSING" or "MEDICINE" and "NUTRITION" were combined: PRIMARY HEALTH CARE OR NURSING OR MEDICINE [atenção primária à saúde (primary health care), saúde da família (family health), estratégia saúde da família (family health estrategy), enfermagem em saúde comunitária (community health nursing), enfermagem em saúdepública (public health nursing), enfermagem de atenção primária (primary care nursing), enfermagem pediátrica (pediatric nursing), registros de enfermagem (nursing records)], medicina comunitária (community medicine), medicina de família e comunidade (family practice) and NUTRITION [estado nutricional (nutritional status), antropometria (anthropometry), vigilância nutricional (nutritional surveillance), crescimento (growth), avaliação nutricional (nutrition assessment)]. Each term was individually crossed with another to guarantee the inclusion of all articles related to the topic. In the case of PubMed, the term Brazil was included in the search.

The decision on the inclusion of items involved two stages: i) screening by reading titles and abstracts, ii) reading methods section or the full text. In the screening stage, publications other than articles, studies conducted outside Brazil, review articles, intervention studies and qualitative research were excluded. In the stage involving reading the methods section or the full text, it was decided to 
include observational studies conducted in Brazil in the context of the basic SUS health network which deal with the monitoring of growthin children aged 0-5 years. At this stage, studies that did not include children under five years of age, studies not performed within the basic SUS health network, studies not focused on infant growth surveillance and studies that only used compound parameters in their analysis (without defining specific aspects of infant growth surveillance) were excluded.The literature search, the selection of studies and classification of items as included or excluded were performed by two reviewers independently. Discrepancies between reviewers were resolved by consensus.

Articles were categorized according to analytical categories: structure (items needed to carry out primary health activities: infrastructure, equipment, materials and supplies, human resources) or processes (sets of activities and procedures employed in the management of resources: management, specific activities related to growth monitoring, healthy eating promotion, prevention and control of nutritional disorders, nutritional care for risk groups). For both categories, articles were entered into Excel spreadsheets for analysis of the evaluation parameters that the authors used in their studies. Parameters were quantified according to their use frequencies.

Articles included in the review were characterized according to author and year of publication, objectives, study setting, subjects (population, professionals, documents/records), study samples, and main results.

\section{Results}

The search strategy identified 1745 documents, not including duplicates or triplicates, in the databases, 1729 of which did not meet the eligibility criteria, resulting in 16 articles for analysis. The process of selection of articles can be seen in Table 1 .

Table 2 shows the general characteristics of the 16 articles 16-31 included in the review. As can be seen, most studies were conducted in the Southeast $(n=8)$ or Northeast $(n=7)$ regions of Brazil, with a single study in the Center West region and none in the South or North regions.

The evaluation of the structure of health units in relation to feeding and nutrition actions (activities such as food and nutrition surveillance, healthy eating promotion, prevention programs and control of nutritional disorders, monitoring of government programs) was considered in only six articles 20 -
$23,25,28$ revealing recurrent problems such as lack of training/knowledge of health professionals to develop activities targeting growth surveillance as well as lack of protocols for these purposes. Some results also show difficulties related to the infrastructure of units or premises for consultations (Table 3).

Results related to working process (Table 4) were considered in 1516-22,24-31 of the 16 articles and the most commonly cited problems were those related to recording growth parameters, particularly the growth curves of the Child Health Record and those concerning the adoption of guidelines on the basis of notes included in the Child Health Record, including those related to growth curves. Failure to assess anthropometric parameters in consultations, especially height, also stands out as a recurring result in several studies.

\section{Discussion}

It can be inferred from the findings of this review that publications related to growth surveillance in the primary public healthcare service network in Brazil are still insufficiently numerous and geographically uneven. Two literature reviews focusing on scientific production in the field of nutrition showed similar results, as they did with regard to evaluative research on growth surveillance and child health care. 9,10 It is argued that these disparities are related to the concentration of graduate programs and research groups in the most developed regions of the country, as well as to differences in investment in research. There is therefore a need to highlight the importance of maintaining strategies that allow a better distribution of scientific production in the country, such as the National Policy for Science, Technology and Innovation in Health, which, from 2004 onwards, established mechanisms to overcome regional research inequalities, with the funding of resources to the order of $30 \%$ for projects whose executive institutions are located in the least developed regions of the country. ${ }^{10}$ The results presented here show that the situation is worst in the North region, while the Northeast region, with scientific production similar to that of the Southern region, still has room for improvement.

In relation to results systematized from studies included in this review, basic aspects in health care priorities were neglected.1,32 Since 2006, children's health was officially established as a strategic part of National Primary Care Policy. 33 These issues are related to both structural conditions and to working 
Table 1

Studies excluded and included in the review of child growth monitoring in the context of the Primary Public Healthcare Service Network in Brazil. Publications from 2006 to the date of the search (24/05/2015).

\begin{tabular}{lc}
\hline Exclusion and inclusion criteria & Number of studies \\
\hline Studies identified (data bases) & 492 \\
$\quad$ SciELO & 711 \\
Lilacs & 1093 \\
PubMed & 423 \\
$\quad$ Duplicate studies (in two databases) & 128 \\
Triplicate studies (in three databases) & 1745 \\
Total studies identified & \\
& \\
Excluded studies & 74 \\
Screening Phase & 82 \\
- Publications of other nature (different articles) & 70 \\
- Studies outside Brazil & 53 \\
- Review studies & 66 \\
- Intervention studies & \\
- Qualitative research & \\
Reading stage of the methods section or in full & 1729 \\
- Studies that did not include children under five years & 16 \\
- Studies not carried out in the basic SUS health network & \\
- Studies not focused on child growth monitoring & 467 \\
- Studies that included only compound parameters & 601 \\
Total studies excluded & 314 \\
Total articles included & 02 \\
\hline
\end{tabular}

\section{Table 2}

Characteristics of articles on child growth monitoring in the context of the Primary Public Healthcare Service Network in Brazil: general characterization. Publications from 2006 to the date of the search (24/05/2015).

\begin{tabular}{|c|c|c|c|}
\hline Author, year & Objectives & Study site & Subjects and sample \\
\hline Palombo CNT et al.,16 2014 & $\begin{array}{l}\text { Evaluate the use and completion } \\
\text { of } \mathrm{CHR} \text {, especially growth and } \\
\text { development in } \mathrm{BHU}\end{array}$ & Small-size municipality, SP & $\begin{array}{l}12 \mathrm{BHU} \\
358 \text { children under three } \\
\text { years and their } \mathrm{CHR}\end{array}$ \\
\hline
\end{tabular}

BFHU= Basic Family Health Unit; BHU= Basic Health Unit; CHR= Child Health Record; FHP= Family Health Program; FHS= Family Health Strategy.

continue 
Characteristics of articles on child growth monitoring in the context of the Primary Public Healthcare Service Network in Brazil: general characterization. Publications from 2006 to the date of the search (24/05/2015).

\begin{tabular}{|c|c|c|c|}
\hline Author, year & Objectives & Study site & Subjects and sample \\
\hline Furtado MCC et al.,18 2013 & $\begin{array}{l}\text { To analyze the presence and } \\
\text { extent of the attributes of prima- } \\
\text { ry care and the degree of affilia- } \\
\text { tion of children under one year of } \\
\text { age in a BFHU }\end{array}$ & São Paulo, SP & $\begin{array}{l}1 \text { BFHU } \\
44 \text { children under one year }\end{array}$ \\
\hline Moreira MDS et al.,192013 & $\begin{array}{l}\text { Describe the growth and develop- } \\
\text { ment records made by nurses in } \\
\text { nursing consultation for children } \\
\text { under two years at BFHU }\end{array}$ & Cuiabá, MT & $\begin{array}{l}4 \mathrm{BFHU} \\
22 \text { medical records and CHR }\end{array}$ \\
\hline Rocha ACD et al.,20 2013 & $\begin{array}{l}\text { Evaluate growth monitoring } \\
\text { actions in the context of primary } \\
\text { health care in the municipality of } \\
\text { Queimadas, Paraíba, Brazil high- } \\
\text { lighting structural and procedural } \\
\text { aspects }\end{array}$ & Queimadas, PB & $\begin{array}{l}16 \text { BFHU } \\
204 \text { childrenbornduring } 2009\end{array}$ \\
\hline Reichert APS et al.,21 2012 & $\begin{array}{l}\text { Check the knowledge and prac- } \\
\text { tices of FHS nurses as to growth } \\
\text { monitoring of infants during rou- } \\
\text { tine childcare and maternal infor- } \\
\text { mation }\end{array}$ & João Pessoa, PB & $\begin{array}{l}53 \text { BFHU } \\
45 \text { nurses } 225 \text { children under } \\
\text { two years }\end{array}$ \\
\hline Costa GD et al.,22 2011 & $\begin{array}{l}\text { Evaluate the health care of the } \\
\text { child by FHP taking distinct sce- } \\
\text { narios as reference }\end{array}$ & Teixeiras, MG & $\begin{array}{l}4 \mathrm{BFHU} \\
35 \text { health professionals } \\
161 \text { children under two years }\end{array}$ \\
\hline Saparolli ECL et al.,23 2010 & $\begin{array}{l}\text { Assess the quality of the structure } \\
\text { available for the nursing consul- } \\
\text { tation given to children under } \\
\text { one year of age at BFHU in São } \\
\text { Paulo }\end{array}$ & São Paulo, SP & $\begin{array}{l}8 \text { BFHU } \\
12 \text { offices intending to } \\
\text { implement the nursing con- } \\
\text { sultation } \\
14 \text { Nurses }\end{array}$ \\
\hline Caldeira AP et al.,24 2010 & $\begin{array}{l}\text { Assess the quality of maternal } \\
\text { and child care in two models of } \\
\text { care (FHS vs. Traditional) }\end{array}$ & Montes Claros, MG & $\begin{array}{l}595 \text { children under two years } \\
\text { ( } 297 \text { FHS vs. } 298 \text { traditional) }\end{array}$ \\
\hline Lima MAAL et al.,25 2010 & $\begin{array}{l}\text { Investigate whether anthropo- } \\
\text { metric data produced in the basic } \\
\text { Brazilian Health System in } \\
\text { Alagoas have satisfactory reliabi- } \\
\text { lity }\end{array}$ & State of Alagoas & $\begin{array}{l}40 \mathrm{BHU} \\
347 \text { children under five years }\end{array}$ \\
\hline Lima GGT et al.,26 2009 & $\begin{array}{l}\text { Analyze whether the growth and } \\
\text { development records of children } \\
\text { within the basic network nursing } \\
\text { consultation context are in agree- } \\
\text { ment with the proposal of the } \\
\text { Ministry of Health }\end{array}$ & João Pessoa, PB & $\begin{array}{l}1 \mathrm{BHU} \\
39 \text { medical records of chil- } \\
\text { dren aged } 0-12 \text { months }\end{array}$ \\
\hline Alves CRL et al.,27 2009 & $\begin{array}{l}\text { To analyze the factors associated } \\
\text { with quality of CHRcompletion in } \\
\text { Belo Horizonte }\end{array}$ & Belo Horizonte, MG & $\begin{array}{l}18 \mathrm{BHU} \\
365 \mathrm{CHR} \text { of children under } \\
\text { one year }\end{array}$ \\
\hline
\end{tabular}

$\mathrm{BFHU}=$ Basic Family Health Unit; BHU= Basic Health Unit; CHR= Child Health Record; FHP= Family Health Program; FHS= Family Health Strategy.

continue 
Characteristics of articles on child growth monitoring in the context of the Primary Public Healthcare Service Network in Brazil: general characterization. Publications from 2006 to the date of the search (24/05/2015).

\begin{tabular}{|c|c|c|c|}
\hline Carvalho MF et al.,28 2008 & $\begin{array}{l}\text { Analyze the growth monitoring } \\
\text { action of children under one year } \\
\text { at BHU in the State of } \\
\text { Pernambuco, Brazil, in 1998, in } \\
\text { relation to structure and process }\end{array}$ & State of Pernambuco & $\begin{array}{l}120 \mathrm{BHU} \\
816 \text { children under one year }\end{array}$ \\
\hline Frota MA et al.,29 2007 & $\begin{array}{l}\text { To assess factors related to } \\
\text { weight anthropometric monitor- } \\
\text { ing by health professionals }\end{array}$ & Fortaleza, CE & $\begin{array}{l}4 \mathrm{BHU} \\
20 \text { health professionals ( } 11 \\
\text { pediatricians and nine nur- } \\
\text { ses) }\end{array}$ \\
\hline Saparolli ECL,30 2007 & $\begin{array}{l}\text { To assess the quality of nursing } \\
\text { consultations given to children } \\
\text { under one year of age at BFHU in } \\
\text { São Paulo }\end{array}$ & São Paulo, SP & $\begin{array}{l}8 \mathrm{BHU} \\
14 \text { nurses and } 114 \text { consulta- } \\
\text { tions to children under one } \\
\text { year of age }\end{array}$ \\
\hline Prado SRLA,31 2006 & $\begin{array}{l}\text { To assess medical records from } \\
\text { two health units, one in the FHS } \\
\text { model and another traditional }\end{array}$ & São Paulo, SP & $\begin{array}{l}1 \mathrm{BFHU} \\
1 \mathrm{BHU} \\
195 \text { records of health facili- } \\
\text { ties related to children aged } \\
0-5 \text { years ( } 99 \mathrm{FHS} \text { vs. } 96 \text { tradi- } \\
\text { tional) }\end{array}$ \\
\hline
\end{tabular}

BFHU= Basic Family Health Unit; BHU= Basic Health Unit; $\mathrm{CHR}=$ Child Health Record; FHP= Family Health Program; FHS= Family Health Strategy.

Table 3

Characteristics of articles on infant growth surveillance in the context of the Primary Public Healthcare Service Network in Brazil: main results of studies focused on structure. Publications from 2006 to the date of the search $(24 / 05 / 2015)$.

\begin{tabular}{ll}
\hline Author, year & \multicolumn{1}{c}{ Main results } \\
\hline Rocha ACD et al., $202013 \quad$ & $-18.7 \%$ of units without all members of the minimum team \\
& $-6.3 \%$ of units without nutritionist and pediatric support at FHSC \\
& $-100 \%$ of units with equipment to measure children \\
& $-6.3 \%$ of units without equipment to weigh children \\
& $-6.3 \%$ of the units without CHR availability \\
& $-62.5 \%$ of nurses untrained in growth monitoring actions \\
& $-25 \%$ of nurses do not use growth monitoring protocols \\
Reichert APS et al.,21 $2012 \quad$ & $-28.9 \%$ of the nurses without knowledge of the risk factors for stunting \\
& $-62.2 \%$ nurses without knowledge of the growth process \\
& $-64.4 \%$ of the nurses without knowledge of the growth curves contained in CHR \\
Costa GD et al.,22 2011 & - Poor and old facilities and hygiene problems \\
& - Care rooms with no sinks \\
& - Presence of Pediatric scale \\
& - Lack of protocols and standards related to growth
\end{tabular}


Characteristics of articles on infant growth surveillance in the context of the Primary Public Healthcare Service Network in Brazil: main results of studies focused on structure. Publications from 2006 to the date of the search (24/05/2015).

\begin{tabular}{|c|c|}
\hline Author, year & Main results \\
\hline Saparolli ECL et al.,23 2010 & $\begin{array}{l}\text { - Mostly satisfactory conditions of offices } \\
\text { - Two offices without sinks } \\
\text { - } 100 \% \text { of offices with material resources (pediatric scale, table for pediatric scale, anthropo- } \\
\text { metric ruler, anthropometric tape) }\end{array}$ \\
\hline Lima MAAL et al.,25 2010 & $\begin{array}{l}\text { - } 40 \% \text { of BHU with suitable locations to perform anthropometry } \\
\text { - Platform scale in } 97.5 \% \text { of units } \\
\text { - Pediatric Balances in } 85 \% \text { of the units, the majority }(73.5 \%) \text { in poor maintenance conditions } \\
\text { - Estadiometer in } 27.5 \% \text { of the units, of which } 36.4 \% \text { in poor conservation status } \\
\text { - Anthropometric tape in } 25 \% \text { of units } \\
\text { - } 18 \% \text { of professionals with training in anthropometry } \\
\text { - } 13 \% \text { of professionals with training in CHR management }\end{array}$ \\
\hline Carvalho MF et al.,28 2008 & $\begin{array}{l}\text { - } 15.8 \% \text { of units without or with insufficient CHR } \\
\text { - Pediatric Balance operating in } 84.2 \% \text { of units } \\
\text { - Program Standards (growth monitoring) in } 24.6 \% \text { of units } \\
-75.3 \% \text { of physicians and } 51.2 \% \text { of nurses untrained in growth monitoring actions }\end{array}$ \\
\hline
\end{tabular}

FHSC= Family Health Support Centers; $\mathrm{CHR}=$ Child Health Record; BHU= Basic Health Unit.

\section{Table 4}

Characteristics of articles on child growth monitoring in the context of the Primary Public Healthcare Service Network in Brazil: main results of studies focused on working processes. Publications from 2006 to the date of the search (24/05/2015).

\begin{tabular}{|c|c|}
\hline Author, year & Main results \\
\hline Palombo CNT et al.,16 2014 & $\begin{array}{l}-8.9 \% \text { of CHR with records in the weight and height curves } \\
-83.7 \% \text { of mothers counseled on child's weight gain and stature }\end{array}$ \\
\hline Costa JSD et al.,17 2014 & $-29.2 \%$ of CHR with no weight record \\
\hline Furtado MCC et al.,18 2013 & $\begin{array}{l}\text { - Most mothers reported receiving information about feeding and growth changes in all me- } \\
\text { dical or nursing consultations }\end{array}$ \\
\hline Moreira MDS et al.,19 2013 & $\begin{array}{l}\text { - CHR showed weight, height, head circumference and BMI records of } 100 \%, 100 \%, 72.7 \% \text { and } \\
22.7 \% \text {, respectively }\end{array}$ \\
\hline Rocha ACD et al.,20 2013 & $\begin{array}{l}-38.7 \% \text { of children with no weight record in the last three months at CHR } \\
-33.8 \% \text { of children with no height record in the last three months at CHR } \\
-17.6 \% \text { of children without at least two weight records in the weight } x \text { age curve of CHR }\end{array}$ \\
\hline Reichert APS et al.,21 2012 & $\begin{array}{l}\text { - } 95.6 \% \text { of nurses reported performing growth monitoring consultation, } 97.8 \% \text { advise the } \\
\text { mothers on child's weight and } 100 \% \text { advise on child's feeding } \\
\text { - } 100 \% \text { of children with growth assessment } \\
\text { - } 54.7 \% \text { of mothers without guidance on the weight curve of CHR } \\
-14.2 \% \text { of mothers unguided about infant feeding }\end{array}$ \\
\hline Costa GD et al.,22 2011 & $\begin{array}{l}-22.8 \% \text { of children without CHR } \\
-100 \% \text { of incomplete CHR (no growth curve on the graph, no information on weight and } \\
\text { height) }\end{array}$ \\
\hline
\end{tabular}


Characteristics of articles on child growth monitoring in the context of the Primary Public Healthcare Service Network in Brazil: main results of studies focused on working processes. Publications from 2006 to the date of the search (24/05/2015).

\begin{tabular}{|c|c|}
\hline Author, year & Main results \\
\hline Caldeira AP et al.,24 2010 & $\begin{array}{l}\text { - Regular record of growth and development in } 75.8 \% \text { of cases in the FHS vs. } 48.3 \% \text { in tradi- } \\
\text { tional services with better performance in the FHS (significant difference) }\end{array}$ \\
\hline Lima MAAL et al.,25 2010 & $\begin{array}{l}\text { - } 15 \% \text { of professionals reported following specific procedures for weight and height collection } \\
-100 \%, 26 \% \text { and } 38 \% \text { of professionals reported recording anthropometric data in the medical } \\
\text { record, nutritional surveillance form and CHR, respectively } \\
-100 \% \text { of children with weight measurement } \\
-25.1 \% \text { of children with height measurement } \\
-91.1 \% \text { of children with weight measurement in the medical record } \\
-13.3 \% \text { of children with weight records at CHR } \\
-87.7 \% \text { of children with height measurements in the medical records }\end{array}$ \\
\hline Lima GGT et al.,26 2009 & $\begin{array}{l}-30.8 \% \text { of children with no weight record } \\
-38.5 \% \text { of children with no height record } \\
-35.9 \% \text { of children with no head circumference record }\end{array}$ \\
\hline Alves CRL et al.,27 2009 & $\begin{array}{l}\text { - } 38.9 \% \text { of mothers without information on the weight } x \text { age curve } \\
\text { - Correct record of birth weight, birth length and head circumference at birth of } 94.1 \%, 91.2 \% \\
\text { and } 85.6 \% \text {, respectively } \\
\text { - Correct record of birth weight, birth length and head circumference at birth of } 69.3 \%, 15.5 \% \\
\text { and } 59.4 \% \text {, respectively }\end{array}$ \\
\hline Carvalho MF et al.,28 2008 & $\begin{array}{l}\text { - } 53.1 \% \text { of children with weight measurement } \\
\text { - } 21 \% \text { of children with height measurement } \\
-89.4 \% \text { of CHR with birth weight record } \\
-44.1 \% \text { of CHR with weight record at birth on the curve } \\
\text { - } 58.2 \% \text { of children with weight records at CHR } \\
\text { - } 43.2 \% \text { of parents guided about growth curves (weight), } 35.5 \% \text { on weight and } 53.5 \% \text { on } \\
\text { stature } \\
\text { - On first consultation, } 54.3 \% \text { of children were weighed, } 20.2 \% \text { were measured, } 22.4 \% \text { with } \\
\text { weight on the curve and } 21.5 \% \text { with guidelines on growth }\end{array}$ \\
\hline
\end{tabular}

Frota MA et al.,29 2007

$-75 \%$ of professionals reported recording weight on the curve at every visit

- $60 \%$ of professionals reported providing guidance to parents about growth curves

Saparolli ECL, $302007 \quad-100 \%$ of children with weight and height measurement

- $79.8 \%$ of children with head circumference measurement, of which $9.8 \%$ on the curve

$-96.7 \%$ of children with adequacy in weighing procedures

$-90.4 \%$ of children with adequacy in measuring procedures

$-86 \%$ of children with weight and height records in the medical records

- $100 \%$ of next appointment scheduling

Prado SRLA, 312006

- Record, respectively, of weight and height, in $97.9 \%$ and $95.9 \%$ of cases in the FHS model unit vs. $91.8 \%$ and $89.7 \%$ in the traditional model unit, with no significant difference - Record on the growth curve in $92.9 \%$ of cases in the FHS model unit vs. $8.3 \%$ in the traditional model unit, with significant difference

$\mathrm{CHR}=$ Child's Health Record; BMI= Body Mass Index; FHS=Family Health Strategy. 
processes, which are essential for the good performance of services and improvements in thehealth status of the population. 34

In Northeast and South Brazil, a study that compared the traditional model of primary care to the model adopted by the Family Health Strategy found, among others, issues related to precariousness and improvisation in the structures of health units. 34 The authors therefore pointed out that primary health care in Brazil is marked by restrictions that compromise service performance and hence impact public health. In the state of Bahia, a recent study with a similar focus,produced similar results. ${ }^{35}$ This is recognized by health professionals, according to the results of a study conducted in the Distrito Federal that indicated dissatisfaction with the physical structure. 36 In the specific case of monitoring growth, a worldwide study foundsimilar deficiencies, including lack of anthropometric equipment. 37 These results are similar to those regarding infrastructure problems in this review, pointing to a shortage of structure at health facilities that may have a negative impact on growth monitoring and system performance.

Deficiencies regarding the training of health team members have beenreported to be one of the major limiting factors in the structure of nutritional assistance during prenatal care in the municipality of Rio de Janeiro. 38 A study carried out in Northeast Brazil reported that the number of health professionals in the Family Health Strategy trained in Public Health has decreased.39 Focusing on Latin America, other researchers have highlighted the shortage of nurses with specific skills to work in primary health care. 40 Studies conducted in the cities of Vitória 41 and Campina Grande 36 have highlighted the importance of training courses for actions performed by primary health professionals. In these studies, when asked about training courses they attended, health professionals reported that the topic of child health was not one of those most commonly mentioned. Another study that examined the history of the Family Health Strategy over the 12 years of implementation, showed that training, qualification and continued education of nurses and other professionals of the Family Health Strategy must be a state policy priority. 42 These results and those previously obtainedpoint to the need for training of health professionals, includingin the field of child growth monitoring.

In terms of growth monitoring, there isneed for continuous training in anthropometry as a way ofpromoting learning and professional development and ensuring that health surveillance objectives are met. ${ }^{43}$ Standardization of measurement procedures and calibration of evaluators are essential to minimize systematic errors (accuracy guarantee), 43,44 which, even if slight, can lead to significant distortions in the nutritional diagnosis. 25 The anthropometry training program recently published by researchers can be recommended for these purposes. 43

The use of protocols is critical for standardization of child growth surveillance. 20 The unavailability of or failure to use protocols, in combination with the results outlined here, have been pointed out in previous studies in the context of the Family Health Strategy. 34,45,46 Managers and health professionals should thus be aware of the Technical Standard of the Ministry of Health's Food and Nutrition Surveillance System. 47 The lack of qualification and the non-use of protocols may compromise diagnosis of nutritional status, identification of risks and optimization/systematization of care. 20,25

There is therefore a need to know which factors negatively influence the structural conditions of health units, despite the regulatory and legislative aspects stipulated by law. Ordinance $N^{\circ} 24.88$ of October 21, 2011, which regulates NationalPrimary Care Policy, thus also stipulatesthe professional assignments, environments, equipment and materials that must be present in each health unit if the set of proposed actions is to be adequately accomplished. 33 In relation to child growth surveillance, there is need for adequate physical spaces and good quality equipment, with recommended maintenance and calibration. It should also be noted that the training of professionals is essential for adequate measurement and understanding of anthropometric measures.33,4749

In terms of working processes, problems relating to height measurement can be associated with more recent incorporation of height $\mathrm{x}$ age curves, as proposed by the 2007 Child Health Record. ${ }^{11}$ To this should be added: 1) lack of training and/or motivation of health professionals; 2) lack of appropriate and/or maintenance of measuring instruments; 3 ) little recognition or ignorance on the part of health professionals of the importance of adequate linear growth, with a detrimental effect on the situation of Brazilian children and prevention by way of timely intervention. 25,50

Continuous recording of anthropometric data is as important as measurement and dependent on it. Similar to results found here, recent articleshave discovered major shortcomings in the records of anthropometric measurements included in the Child Health Record child health surveillance tool.11,13 It 
is recommended that anthropometric data be recorded during all consultations regardless of the child's condition, such as nutritional risk, as this is the most appropriate way to monitor child growth in the primary health care.1,32 Continuous care, ensuring the follow-up of the growth monitoring schedule, as proposed in the Appointments Agenda for Comprehensive Child Health and Reduction of Infant Mortality, 32 enables data to be shared among professionals and provides indispensable and extended follow-up of the full care offered and helps identify situations of risk. $1,12,32$

One of the main problems that researchers found with analysis of the information contained in Child Health Recordsby literature review was that the anthropometric data records are not transferred to the curves and that guidance to parents based on the notes recorded was insufficent, 11 as found in the present study also. Another literature review found the main factors explaining the difficulty health professionals experienced using the Child Health Recordsproperly, in such a way that they could be applied to barriers to the development of growth monitoring actions, to belack of training in the use of this instrument, insufficient time, unavailability of the instrument in health services, non-use of the instrument by all members of the healthcare team, and lack of awareness of its importance on the part of mothers/families. 12 Another possible difficulty may be the fact that recommendations for the use of the Child Health Record 14 may be out of date and not reflect changing versions.

Thus, despite evidence indicating the importance of the Child Health Record for health professionals, it was also found that the latter face various difficulties in its use and that investment in qualification is needed to minimize these limitations $11,12,50$ Such issues have also been highlighted in literature on evaluative analysis of Primary Health Care.6,35,51 In relation to growth monitoring, therefore, two aspects may be highlighted: i) the use and interpretation of growth curves is one of the major difficulties faced by professionals, ${ }^{11,12}$ as found in research involving 178 countries, 37 ii) the lack of expertise on the part of professionals in implementation ofhigh-quality actions, ${ }^{11,12}$ as reflected in the need for training and standardization of pediatric practices found in research involving 11 European countries. 52 To meet the challenge of professionaltraining, researchers from UNICEF presented recommendations in an article published for this purpose. ${ }^{2}$

The difficulties found regarding working processes also reflect the challenges related to the development of the Food and Nutrition Surveillance
System. This system has been relegated to the sidelines and lacks analytical or universal features. 53 Moreover, it has not been prioritized in evaluative research on its functioning. 9 The results of two recent surveys thus indicatea low percentage of system utilization and coverage in the states of Rio Grande do Sul54 and São Paulo. 55

Despite the low operational cost of child growth monitoring, which classifies it as a feasible health care technology, 56 the daily life of public health services in Brazil seems to be different. It has been suggested that growth monitoring may improve the utilization of health services, which, in turn, along with maternal education regarding food and nutrition, has a positive effect on nutritional status and health. However, it has been stressed that,for growth monitoringto have effect on nutritional status, the action must involve nutritional counseling and be part of a comprehensive program. In addition, the impact is conditioned by coverage, intensity of contact, performance of professionals, adequacy of resources and involvement of families.2,3 With regard to family involvement, the shared responsibility of families and health professionals for use and accurate completion of the Child Health Record should be emphasized.13,57 There is therefore a need to ensure the structural and procedural conditions that are basic requirements for growth monitoring and the multiple factors that should be considered for actionsto have the desired effects.

The results of the present review suggest limitations regarding the geographical concentration of studies and generalizations should be made with the greatest of care. Studies should therefore be conducted in the Center West, South and North regions of Brazil to establish comparisons between geographical realities and different resources. Likewise, the impossibility of generalizing the design of some of the systematic studies suggests the need for research that better guarantees representation. Despite these restrictions, the relevance of the results comes from the evidence provided on the problems faced whenmonitoring the growth of Brazilian children that underline the need for changes aimed at better implementation of primary health care.

It was concluded that there are few studies of growth surveillance in the context of theprimary public healthcare service network in Brazil and that these tend to be concentrated in certain geographical regions. However, when the results of 16 studies are used, the main obstacles in terms of structure and working processes to growth monitoring programs in primary care are highlighted. In terms of structure, 
deficiencies in training/knowledge of professionals, availability of protocols and physical infrastructure were the main barriers described. In the case of working processes, the main difficulties found were height measurement, recording of growth parameters and use of the Child Health Record to guide parents or provide monitoring using growth curves. Thisis the everyday reality of public health services,

\section{References}

1. Brasil. Ministério da Saúde. Secretaria de Atenção à Saúde. Departamento de Atenção Básica. Saúde da criança: crescimento e desenvolvimento. Brasília, DF; 2012.(Cad Atenção Básica; 33).

2. Mangasaryan N, Arabi M, Schultink W. Revisiting the concept of growth monitoring and its possible role in community-based nutrition programs. Food Nut Bull. 2011; 32 (1): 42-53.

3. Ashworth A, Shrimpton R, Jamil K. Growth monitoring and promotion: review of evidence of impact. Mat Child Nut. 2008; 4: 86-117.

4. Ribeiro LCC, Rocha RL, Ramos-Jorge ML. Acolhimento às crianças na atenção primária à saúde: um estudo sobre a postura dos profissionais das equipes de saúde da família. Cad Saúde Pública. 2010; 26 (12): 2316-22.

5. Campos RMC, Ribeiro CA, Silva CV, Saparolli ECL.Consulta de enfermagem em puericultura: a vivência do enfermeiro na Estratégia de Saúde da Família. Rev Esc Enferm USP. 2011; 45 (3): 566-74.

6. Andrade GN. Vivências dos profissionais da atenção primária à saúde com a caderneta de saúde da criança [dissertação]. Belo Horizonte: Universidade Federal de Minas Gerais; 2011.

7. Abdon JB, Dodt RCM, Vieira DP, Martinho NJ, Carneiro EP, Ximenes LB. Auditoria dos registros na consulta de enfermagem acompanhando o crescimento e desenvolvimento infantil. Rev Rene. 2009; 10 (3): 90-6.

8. Monteiro AI, Macedo IP, Santos ADB, Araújo WM. A enfermagem e o fazer coletivo: acompanhando o crescimento e o desenvolvimento da criança. Rev Rene. 2011; 12 (1): 73-80.

9. Vasconcelos IAL, Snatos LMP. Research potential of food and nutrition in the Family Health Strategy: A structured review. Rev Nutr. 2014; 27 (1): 107-26.

10. Canella DS, Silva ACF, Jaime PC. Produção científica sobre nutrição no âmbito da Atenção Primária à Saúde no Brasil: uma revisão de literatura. Ciênc Saúde Colet. 2013; 18 (2): 297-308.

11. Gaíva MAM, Silva FB. Caderneta de saúde da criança: revisão integrativa. Rev Enferm UFPE online. 2014; 8 (3): 742-9.

12. Abreu TGT, Viana LS, Cunha CLF. Desafios na utilização da caderneta de saúde da criança: entre o real e o ideal. J Manag Prim Health Care. 2012; 3 (2): 80-3.

13. Almeida AC, Mendes LC, Sad IR, Ramos EG, Fonseca VM, Peixoto MVM. Uso de instrumento de acompanhamento do although growth surveillance is a cost-effective and feasible action with proven benefits for health services and for the population. There is, therefore, a need for more comprehensive research to establish a more consistent overview of the national reality based on the preliminary results of the present study, to improve and expand knowledge and practices regarding childcare. crescimento e desenvolvimento da criança no Brasil Revisão sistemática de literatura. Rev Paul Pediatr. 2016; 34 (1): 122-31.

14. Brasil. Ministério da Saúde. Secretaria de Atenção à Saúde. Departamento de Ações Programáticas Estratégicas. Manual para utilização da Caderneta de Saúde da Criança. Brasília, DF; 2005.

15. WHO (World Health Organization). WHO Child Growth Standards: length/height-for-age, weight-for-age, weightfor-length, weight-for-height and body mass index-for-age: methods and development. Geneva; 2006.

16. Palombo CNT, Duarte LS, Fujimori E, Toriyama ATM.Uso e preenchimento da caderneta de saúde da criança com foco no crescimento e desenvolvimento. Rev Esc Enferm USP. 2014; 48 (Esp): 60-7.

17. Costa JSD, Cesar JA, Pattussi MP, Fontoura LP, Barazzetti L, Nunes MF, Gaedke MA, Uebel R.Assistência à criança: preenchimento da caderneta de saúde em municípios do semiárido brasileiro. Rev Bras Saúde Matern Infant. 2014;14 (3): 219-27.

18. Furtado MCC, Braz JC, Pina JC, Mello DF, Lima RAG. A avaliação da atenção à saúde de crianças com menos de um ano de idade na Atenção Primária. Rev Latino-Am Enfermagem. 2013; 21 (2): 1-8.

19. Moreira MDS, Gaíva MAM. Acompanhamento do crescimento e desenvolvimento infantil: análise dos registros das consultas de enfermagem. Pesq Cuid Fundam Online. 2013;5 (2): 3757-66.

20. Rocha ACD, Pedraza DF. Acompanhamento do crescimento infantil em unidades básicas de saúde da família do município de Queimadas, Paraíba, Brasil. Texto Contexto Enferm. 2013; 22 (4): 1169-78.

21. Reichert APS, Almeida AB, Souza LC, Silva MEA, Collet N. Vigilância do crescimento infantil: conhecimento e práticas de enfermeiros da atenção primária à saúde. Rev Rene. 2012; 13 (1): 114-26.

22. Costa GD, Cotta RMM, Reis JR, Ferreira MLSM, Reis RS, Franceschini SCC. Avaliação da atenção à saúde da criança no contexto da Saúde da Família no município de Teixeiras, Minas Gerais (MG, Brasil). Ciênc Saúde Colet. 2011; 16 (7): 3229-40.

23. Saparolli ECL, Adami NP. Avaliação da estrutura destinada à consulta de enfermagem à criança na atenção básica. Rev Esc Enferm USP. 2010; 44 (1): 92-8.

24. Caldeira AP, Oliveira RM, Rodrigues OA. Qualidade da assistência materno-infantil em diferentes modelos de 
Atenção Primária.Ciênc Saúde Colet. 2010; 15 (Supl. 2): S3139-47.

25. Lima MAA, Oliveira MAA, Ferreira HS. Confiabilidade dos dados antropométricos obtidos em crianças atendidas na Rede Básica de Saúde de Alagoas. Rev Bras Epidemiol. 2010; 13 (1): 69-82.

26. Lima GGT, Silva MFOC, Costa TNA, Neves AFGB, Dantas RA, Lima ARSO. Registros do enfermeiro no acompanhamento do crescimento e desenvolvimento: enfoque na consulta de puericultura. Rev Rene. 2009; 10 (3): 117-24.

27. Alves CRL, Lasmar LMLBF, Goulart LMHF, Alvim CG, Maciel GVR, Viana MRA, Colosimo EA, Carmo GAA, Costa JGD, Magalhães MEN, Mendonça ML, Beirão MMV, Moulin ZS.Qualidade do preenchimento da Caderneta de Saúde da Criança e fatores associados. Cad Saúde Pública. 2009; 25 (3): 583-95.

28. Carvalho MF, Lira PIC, Romani SAM, Santos IS, Veras AACA, Batista Filho M. Acompanhamento do crescimento em crianças menores de um ano: situação nos serviços de saúde em Pernambuco, Brasil. Cad Saúde Pública. 2008; 24 (3): $675-85$.

29. Frota MA, Pordeus AMJ, Forte LB, Vieira LJES. Acompanhamento antropométrico de crianças: o ideal e o realizado. Rev Baiana Saúde Pública. 2007; 31 (2): 212-22.

30. Saparolli ECL, Adami NP. Avaliação da qualidade da consulta de enfermagem à criança no Programa de Saúde da Família. Acta Paul Enferm. 2007; 20 (1): 55-61.

31. Prado SRLA, Fujimori E. Registro em prontuário de crianças e a prática da integralidade.Rev Bras Enferm. 2006; 59 (1): 67-71.

32. Brasil. Ministério da Saúde. Secretaria de Atenção à Saúde. Departamento de Ações Programáticas Estratégicas. Agenda de compromissos para a saúde integral da criança e redução da mortalidade infantil. Brasília, DF; 2004. (Série A. Normas e Manuais Técnicos).

33. Brasil. Ministério da Saúde. Secretaria de Atenção à Saúde. Departamento de Atenção Básica. Política Nacional de Atenção Básica. Brasília, DF; 2012.

34. Facchini LA, Piccini RX, Tomasi E, Thumé E, Silveira DS, Siqueira FV, Rodrigues MA. Desempenho do PSF no Sul e no Nordeste do Brasil: avaliação institucional e epidemiológica da atenção básica à saúde. Ciênc Saúde Colet. 2006; 11: 669-81.

35. Moura BLA, Cunha RC, Fonseca ACF, Aquino R, Medina MG, Vilasbôas ALQ, Xavier AL, Costa AF.Atenção primária à saúde: estrutura das unidades como componente da atenção à saúde. Rev Bras Saúde Matern Infant. 2010; 10 (Supl. 1): S69-81.

36. Araújo RL, Mendonça AVM, Sousa MF. Percepção dos usuários e profissionais de saúde no Distrito Federal: os atributos da atenção primária. Saúde Debate. 2015; 39 (105): 387-99.

37. Onis M, Wijnhoven TM, Onyango AW. Worldwide practices in child growth monitoring. J Pediatr. 2004; 144 (4): 461-5.

38. Niquini RP, Bittencourt SA, Lacerda EMA, Saunders C, Leal MC. Avaliação da estrutura de sete unidades de saúde da família para a oferta da assistência nutricional no prénatal no município do Rio de Janeiro, Brasil. Rev Bras Saúde Matern Infant. 2010; 10 (Supl. 1): S61-8.
39. Machado MH. Perfil dos médicos e enfermeiros do Programa Saúde da Família no Brasil: relatório final. Região Nordeste. Brasília, DF; 2000.

40. Ceitlin J. La medicina familiar en América Latina. Presentación. Aten Primaria. 2006; 38 (9): 511-4.

41. Silva VG, Motta MCS, Zeitoune RCG. A prática do enfermeiro na Estratégia Saúde da Família: o caso do município de Vitória/ES. Rev Eletr Enf. 2010; 12 (3): 441-8.

42. Sousa MF, Hamann EM. Programa Saúde da Família no Brasil: uma agenda incompleta? Ciênc Saúde Colet. 2009; 14 (Supl. 1): 1325-35.

43. Bagni UV, Barros DC. Capacitação em antropometria como base para o fortalecimento do Sistema de Vigilância Alimentar e Nutricional no Brasil. Rev Nutr. 2012; 25 (3): 393-402.

44. Castro V, Moraes AS, Freitas ICM, Mondini L. Variabilidade na aferição de medidas antropométricas: comparação de dois métodos estatísticos para avaliar a calibração de entrevistadores. Rev Bras Epidemiol. 2008; 11 (2): 278-86.

45. Ataka T, Oliveira LSS. Utilização dos Protocolos de Enfermagem no Programa de Saúde da Família no Município de São Paulo. Saúde Colet. 2007; 3 (13): 19-24.

46. Costa GD, Cotta RMM, Reis JR, Siqueira-Batista R, Gomes AP, Franceschini SCC. Avaliação do cuidado à saúde da gestante no contexto do Programa Saúde da Família. Ciênc Saúde Colet. 2009; 14 (Sup. 1): 1347-57.

47. Brasil. Ministério da Saúde. Secretaria de Atenção à Saúde. Departamento de Atenção Básica. Orientações para a coleta e análise de dados antropométricos em serviços de saúde: Norma Técnica do Sistema de Vigilância Alimentar e Nutricional - SISVAN. Brasília, DF; 2011.

48. Brasil. Ministério da Saúde. Secretaria de Atenção à Saúde. Departamento de Atenção Básica. Autoavaliação para a Melhoria do Acesso e da Qualidade da Atenção Básica AMAQ. Brasília, DF; 2012.

49. Brasil. Ministério da Saúde. Secretaria de Atenção à Saúde. Departamento de Atenção Básica. Manual de estrutura física das unidades básicas de saúde: saúde da família. Brasília (DF); 2008.

50. Linhares AO, Gigante DP, Bender E, Cesar JA. Avaliação dos registros e opinião das mães sobre a caderneta de saúde da criança em unidades básicas de saúde, Pelotas, RS. AMRIGS. 2012; 56 (3): 245-50.

51. Souza MG, Mandu ENT, Elias AN. Percepções de enfermeiros sobre seu trabalho na estratégia saúde da família. Texto ContEnferm. 2013; 22 (3): 772-9.

52. Scherdel P, Salaün JF, Robberecht-Riquet MN, Reali L, Páll G, Jäger-Roman E,Crespo MP, Moretto M, Seher-Zupančič M, Agustsson S; European Confederation of Primary Care Paediatricians Research Group, Chalumeau M. Growth Monitoring: A Survey of Current Practices of Primary Care Paediatricians in Europe. PLoS ONE. 2013; 8 (8): e70871.

53. Camilo SMB, Camilo GBC, Toledo GC, Camilo Júnior RD, Toledo CC. Vigilância nutricional no Brasil: criação e implementação do SISVAN. Rev APS. 2011; 14 (2): 224-8.

54. Jung NM, Bairros FS, Neutzling MB. Utilização e cobertura do Sistema de Vigilância Alimentar e Nutricional no Estado do Rio Grande do Sul, Brasil.Ciên Saúde Colet. 
2014; 19 (5): 1379-88

55. Enes CC, Loiola H, Oliveira MRM. Cobertura populacional do Sistema de Vigilância Alimentar e Nutricional no Estado de São Paulo, Brasil. Ciên Saúde Colet. 2014; 19 (5): 154351 .

56. Mello DF, Furtado MCC, Fonseca LMM, Pina JC. Seguimento da saúde da criança e a longitudinalidade do cuidado.RevBrasEnferm. 2012; 65 (4): 675-9.

Recebido em 9 de outubro de 2015

Versão final apresentada em 29 de dezembro de 2015

Aprovado em 5 de janeiro de 2016
57. Blanco e Silva F, Gaíva MAM, Mello DF. Utilização da caderneta de saúde da criança pela família: percepção dos profissionais. Texto Contexto Enferm. 2015; 24 (2): 40714. 